\title{
FAKTOR-FAKTOR YANG BERPENGARUH TERHADAP NIAT KEAKTIFAN LANSIA DALAM MENGIKUTI POSYANDU LANSIA
}

\author{
DETERMINANT FACTORS TO LIVELINESS OF ELDERLY IN \\ PARTICIPATING ELDERLY INTEGRATED HEALTH POST
}

\author{
Mindianata Putri \\ Departemen Promosi Kesehatan dan Ilmu Perilaku, Fakultas Kesehatan Masyarakat \\ Universitas Airlangga, Surabaya \\ Email : mindianatta@gmail.com
}

\begin{abstract}
Healthy aged qualified refers to the concept of active aging WHO As an effort of the Government in improving the health status of old age, one of them is by establishing Posyandu Lansia. Puskesmas Bulak Banteng is a health center that oversees 3 Elderly Integrated Health Post (Posyandu) with the lowest Elderly Integrated Health Post (Posyandu) membership rate in Surabaya. The purpose of this study is to analyze the influence of Attitudes toward Behavior, Subjective Norm, and Perceived Behavioral Control to Active Intent follow Elderly Integrated Health Post (Posyandu). This research is a type of observational analytical research with quantitative approach. Based on data retrieval time, this research is a cross sectional study. The result of this research indicate that attitude toward behavior influence to respondent intention to actively follow Elderly Integrated Health Post (Posyandu) with value (sig 0,008) and (Exp (B) 11,25). Subjective norms do not show any significant effect on respondent's intention to actively follow Elderly Integrated Health Post (Posyandu). While the perceived Behavior Control has an effect on the respondent's intention to actively follow Elderly Integrated Health Post (Posyandu) with value (sig 0,002) and $(\operatorname{Exp}(B) 0,236)$. So there is an effort to improve the elderly attitude to actively follow Elderly Integrated Health Post (Posyandu) through the improvement of elderly knowledge about health and Elderly Integrated Health Post (Posyandu) and optimization of health education in Elderly Integrated Health Post (Posyandu) as well as effort to facilitate access time to reach Elderly Integrated Health Post (Posyandu) activity.
\end{abstract}

Keyword: liveliness, elderly, elderly integrated health post (posyandu)

\begin{abstract}
Abstrak: Lanjut usia sehat berkualitas mengacu pada konsep active ageing WHO. Upaya Pemerintah dalam meningkatkan derajat kesehatan usia lanjut, salah satunya ialah dengan membentuk Posyandu Lansia. Puskesmas Bulak Banteng merupakan Puskesmas yang membawahi 3 Posyandu Lansia dengan angka kepesertaan Posyandu Lansia terendah di Surabaya. Tujuan penelitian ini yaitu untuk menganalisis pengaruh sikap terhadap perilaku, norma subyektif, dan kontrol perilaku yang dirasakan terhadap niat aktif mengikuti Posyandu Lansia. Penelitian ini merupakan jenis penelitian analitik observasional dengan pendekatan kuantitatif. Berdasarkan waktu pengambilan data, penelitian ini merupakan penelitian cross sectional. Hasil dari penelitian ini menunjukkan bahwa Sikap terhadap perilaku berpengaruh terhadap niat responden untuk aktif mengikuti Posyandu Lansia dengan nilai (sig. 0,008) dan $(\operatorname{Exp}(B) 11,25)$. Norma subyektif tidak menunjukkan adanya pengaruh yang signifikan terhadap niat responden untuk aktif mengikuti Posyandu Lansia. Sedangkan Kontrol Perilaku yang dirasakan berpengaruh terhadap niat responden untuk aktif mengikuti Posyandu Lansia dengan nilai (sig. 0,002) dan (Exp(B) 0,236). Maka perlu adanya upaya untuk meningkatkan sikap lansia untuk aktif mengikuti Posyandu Lansia melalui peningkatan pengetahuan lansia tentang kesehatan dan Posyandu Lansia dan pengoptimalan penyuluhan kesehatan di Posyandu serta upaya untuk memudahkan akses waktu untuk menjangkau kegiatan Posyandu Lansia.
\end{abstract}


Kata Kunci: keaktifan, lanjut usia, posyandu lansia

\section{PENDAHULUAN}

Kesehatan merupakan suatu keadaan yang seimbang dan dinamis antara tubuh seseorang dengan fungsi dan berbagai faktor yang mempengaruhinya. Sehingga kesehatan menjadi suatu indikator tinggi atau rendahnya kualitas hidup seseorang. Hal ini juga ditulis dalam Undang-Undang Republik Indonesia Nomor 36 Tahun 2009 Tentang Kesehatan Pasal 1 Ayat 1 bahwa kesehatan merupakan keadaan sejahtera secara fisik, mental, spiritual dan sosial yang memungkinkan setiap orang untuk hidup produktif secara sosial dan ekonomis.

Asia menempati urutan pertama dengan populasi lansia terbesar, dimana pada tahun 2015 berjumlah 508 juta populasi lansia dan menyumbang $56 \%$ dari total lansia di dunia. Sejak tahun 2000, persentase penduduk lansia Indonesia melebihi 7\% (Kemenkes RI, 2014). Menurut Soewono dalam Suardiman (2011) suatu negara dapat diakatakan berstruktur tua apabila populasi penduduk lansia melebihi $7 \%$. Hal ini menunjukkan bahwa Indonesia mulai masuk ke dalam kelompok negara berstruktur tua (ageing population). Menurut United Nations, pada tahun 2013 populasi penduduk lansia Indonesia yang berumur 60 tahun atau lebih berada pada urutan 108 dari 196 negara di seluruh dunia. Angka ini tentunya masih dikategorikan belum terlalu besar. Akan tetapi diprediksikan pula bahwa di tahun 2050, Indonesia akan masuk menjadi 10 besar negara dengan jumlah lansia terbesar, yaitu sekitar 10 juta lansia (United Nations, 2013).

Keberhasilan

pembangunan kesehatan berdampak pada peningkatan Usia Harapan Hidup (UHH) seseorang. Sehingga secara global populasi lansia diprediksi terus mengalami peningkatan. Dalam Infodatin Lansia (2016), populasi lansia di Indonesia diprediksi meningkat lebih tinggi dari pada populasi lansia di dunia setelah tahun 2100. Struktur ageing population merupakan cerminan dari semakin tingginya rata-rata Usia Harapan Hidup (UHH) penduduk Indonesia. Tingginya UHH merupakan salah satu indikator keberhasilan pencapaian pembangunan nasional terutama di bidang kesehatan. Sejak tahun 2004-2015 memperlihatkan adanya peningkatan Usia Harapan Hidup di Indonesia dari 68,6 tahun menjadi 70,8 tahun dan proyeksi tahun 2030-2035 mencapai 72,2 tahun.

Lanjut usia sehat berkualitas mengacu pada konsep active ageing WHO yaitu proses penuaan yang tetap sehat secara fisik, sosial dan mental sehingga dapat tetap sejahtera sepanjang hidup dan tetap berpartisipasi dalam rangka meningkatkan kualitas hidup sebagai anggota masyarakat. Berdasarkan Undang Undang Nomor 13 Tahun 1998 tentang Kesejahteraan Lanjut Usia, lanjut usia adalah seseorang yang mencapai usia 60 tahun ke atas.

Pemerintah memiliki kewajiban untuk menjamin ketersediaan pelayanan kesehatan dan memfasilitasi kelompok lanjut usia agar tetap dapat hidup sehat, mandiri, serta produktif. Hal ini diperkuat dengan adanya peraturan Undang-Undang No. 36 Tahun 2009 Pasal 138 bahwa upaya pemeliharaan kesehatan bagi lanjut usia harus ditujukan untuk menjaga agar tetap hidup sehat dan produktif secara sosial maupun ekonomi sesuai dengan martabat kemanusiaan.

Dalam Peraturan Daerah Kota Surabaya tahun 2014, kelompok lansia atau dikenal juga dengan sebutan Pos Pelayanan Terpadu (Posyandu) Lanjut Usia atau Pos Pembinaan Terpadu (Posbindu) yang termasuk dalam komponen program kesehatan lansia pada poin ketiga adalah suatu wadah pelayanan kesehatan bersumber daya masyarakat (UKBM) untuk melayani penduduk lansia, yang proses pembentukan dan pelaksanaannya dilakukan oleh masyarakat bersama lembaga swadaya masyarakat (LSM), lintas sektor 
pemerintah dan non-pemerintah, swasta, organisasi sosial dan lain-lain, dengan menitikberatkan pelayanan kesehatan pada upaya promotif dan preventif.

Sebagai upaya Pemerintah dalam meningkatkan derajat kesehatan usia lanjut, salah satunya ialah dengan membentuk Posyandu Lansia. Tujuan diadakannya Posyandu Lansia yaitu untuk meningkatkan pengetahuan, sikap, perilaku positif, serta meningkatkan mutu dan derajat kesehatan lansia. Sehingga diperlukan kemauan yang kuat bagi lansia dalam mengikuti kegiatan Posyandu yang diadakan rutin oleh kader Posyandu. Dalam penelitian ini akan dipaparkan mengenai faktor-faktor yang berhubungan dengan perilaku keaktifan lansia dalam mengikuti Posyandu Lansia.

Tujuan diadakannya Posyandu Lansia yaitu untuk meningkatkan pengetahuan, sikap, perilaku positif, serta meningkatkan mutu dan derajat kesehatan lansia. Sehingga diperlukan kemauan yang kuat bagi lansia dalam mengikuti kegiatan Posyandu yang diadakan rutin oleh kader Posyandu (Suseno, 2012).

Perilaku aktif dalam mengikuti kegiatan Posyandu Lansia dapat meminimalkan permasalahan kesehatan Lansia yang muncul akibat proses penuaan, karena penyakit dapat dideteksi secara dini. Selain itu aktif mengikuti Posyandu Lansia juga dapat meningkatkan derajat kesehatan serta Usia Harapan Hidup (Mamik, 2013).

Berdasarkan data Badan Pusat Statistik tahun 2014, populasi lansia di Indonesia mencapai 20,24 juta jiwa, setara dengan $8,03 \%$ dari seluruh penduduk Indonesia. Menurut Infodatin Lansia tahun 2016, Jumlah Posyandu Lansia terbanyak berada di Provinsi Jawa Timur yaitu berjumlah 54.522 Posyandu Lansia. Jawa Timur dengan jumlah Posyandu Lansia tertinggi ini berbanding lurus dengan persentase populasi lansia di provinsi tersebut yang menempati urutan ketiga tertinggi di Indonesia. Dinas Kesehatan Kota Surabaya membawahi 63 Puskesmas dengan 685 Posyandu Lansia dan jumlah peserta sebesar 57.204 orang.
Puskesmas Bulak Banteng memiliki angka penduduk lansia yang cukup tinggi yaitu sebesar 5.671 jiwa. Jumlah kepesertaan Posyandu Lansia berdasarkan data Dinas Kesehatan Kota Surabaya (2017), Puskesmas Bulak Banteng merupakan Puskesmas yang membawahi 3 Posyandu Lansia dengan angka kepesertaan Posyandu Lansia terendah di Surabaya yaitu berjumlah 215 peserta dimana jumlah Lansia sebanyak 70 orang dari Posyandu Yuswoaji, 70 orang dari Posyandu Ceria dan 75 orang dari Posyandu Kenanga. Berdasarkan hasil perhitungan target cakupan pelaksanaan Posyandu Lansia di Puskesmas Bulak Banteng dihasilkan sebuah angka yaitu sebesar 3,79\%. Artinya bahwa persentase kepesertaan di Posyandu Lansia Bulak Banteng hanya sebesar 3,79\% dan belum mencapai target yang telah ditetapkan.

Banyak faktor yang tentunya berpengaruh dalam pengambilan keputusan lansia untuk berperilaku aktif mengikuti Posyandu Lansia. Pengambilan keputusan tersebut didasari oleh sebuah kesadaran, yang berawal dari niat (intensi) sehingga terbentuk suatu perilaku. Pemilihan menggunakan Theory of Planned Behavior dalam penelitian ini didasarkan pada fungsi teori untuk melihat pengaruh sikap terhadap perilaku, norma subyektif, dan kontrol perilaku yang dirasakan terhadap niat seseorang. Tujuan penelitian ini yaitu untuk menganalisis pengaruh sikap terhadap perilaku, norma subyektif, dan kontrol perilaku yang dirasakan terhadap Niat aktif mengikuti Posyandu Lansia.

\section{METODE}

Penelitian ini merupakan jenis penelitian analitik observasional yaitu suatu penelitian yang menetukan adanya hubungan antara satu variabel dengan variabel lainnya dengan pendekatan kuantitatif.

Lansia yang menjadi responden penelitian harus memenuhi kriteria inklusi, yaitu antara lain : 1.) Berusia 4575 tahun, 3.) Tidak mengalami masalah pendengaran, 4.) Mandiri dalam hal membaca dan menulis (tidak memerlukan 
bantuan orang lain untuk pada saat membaca dan menulis). Sampel dalam penelitian ini dipilih menggunakan teknik simple random sampling dimana penentuan terhadap populasi setiap anggota populasi memiliki kesempatan yang sama untuk menjadi sampel penelitian. Langkah pertama dalam pengambilan sampel yaitu, peserta Posyandu Lansia sejumlah 139 orang dari total populasi 215 orang yang telah memenuhi kriteria inklusi penelitian diberikan nomor urut. Langkah selanjutnya, 139 peserta tersebut di lotre oleh petugas Posyandu untuk menentukan siapa yang akan menjadi responden penelitian dan mendapatkan kuesioner. Apabila dari hasil lotre yang keluar adalah angka 9, maka peserta dengan nomor urut 9 akan menjadi subjek penelitian. Sehingga didapatkan responden yang mendapatkan lotre sesuai dengan jumlah sampel yang dibutuhkan, yaitu sebanyak 87 orang.

Lokasi penelitian bertempat di Posyandu Lansia Puskesmas Bulak Banteng Surabaya. Sedangkan waktu pengambilan data dilakukan pada bulan Februari-Maret 2018.

Variabel independen dalam penelitian ini adalah sikap terhadap perilaku, norma subyektif, dan kontrol perilaku yang dirasakan. Sedangkan Variabel terikat dalam penelitian ini adalah niat keaktifan lansia dalam mengikuti Posyandu Lansia.

Mekanisme pengumpulan data diawali dengan pemaparan tujuan dan Penjelasan Sebelum Persetujuan (PSP) yang dilakukan sebelum kegiatan Posyandu Lansia berlangsung. Hal ini dilakukan agar peserta Posyandu Lansia tidak menunggu hingga semua peserta selesai diperiksa. Peserta Posyandu Lansia yang selesai terlebih dahulu dapat melakukan pengisian kuesioner secara langsung sesuai dengan penjelasan yang telah dipaparkan sebelumnya.

Teknik pengumpulan data pada penelitian ini menggunakan teknik skoring yang selanjutnya akan dianalisis dengan maksud untuk melihat pengaruh sikap terhadap perilaku, norma subyektif, dan kontrol perilaku yang dirasakan terhadap niat aktif mengikuti Posyandu
Lansia menggunakan uji regresi logistik. Sebelum dianalisis, tiap variabel dependen memiliki skor yang selanjutnya akan dikategorikan berdasarkan tingkatannya yaitu kurang baik, baik, dan sangat baik. Sedangkan untuk variabel independen dikategorikan kedalam memiliki niat dan tidak memiliki niat.

Variabel dependen diukur menggunakan 6 skala. Berdasarkan rentang nilai total untuk sikap (AB), yakni $5 \leq \mathrm{AB} \leq 180$, secara langsung dibagi menjadi tiga berdasarkan sifat pengaruh nilai $\mathrm{AB}$ tersebut terhadap niat berperilaku aktif, yaitu: $5 \leq \mathrm{AB}<60=$ kurang baik, $60 \leq \mathrm{AB}<120=$ baik, 120 $\leq \mathrm{AB} \leq 180=$ sangat baik. Rentang nilai total untuk norma subyektif (SN), yakni 6 $\leq \mathrm{SN} \leq 216$, secara langsung dibagi menjadi tiga berdasarkan sifat pengaruh nilai SN tersebut terhadap niat berperilaku aktif, yaitu : $6 \leq \mathrm{SN}<70=$ kurang baik, $70 \leq \mathrm{SN}<140=$ baik, $140 \leq \mathrm{SN} \leq 216=$ sangat baik. Sedangkan rentang nilai total untuk kontrol perilaku yang dirasakan (PBC), yakni $5 \leq \mathrm{PBC} \leq 180$, secara langsung dibagi menjadi tiga berdasarkan sifat pengaruh nilai $\mathrm{PBC}$ tersebut terhadap niat berperilaku aktif, yaitu : $5 \leq \mathrm{PBC}<$ $60=$ kurang baik, $60 \leq \mathrm{PBC}<120=$ baik, $120 \leq \mathrm{PBC} \leq 180=$ sangat baik.

Data tersebut selanjutnya ditabulasi dan dianalisis secara deskriptif dan analitik dengan menggunakan uji statistik Regresi Logistik untuk mengetahui pengaruh antara variabel bebas terhadap variabel terikat. Uji statistik tersebut menggunakan $(\alpha=5 \%)$. Data Hasil observasi yang diperoleh dikumpulkan kemudian diolah dan disajikan dalam bentuk tabel yang kemudian diolah dan dianalisis secara deskriptif.

\section{HASIL DAN PEMBAHASAN}

Berdasarkan hasil pengolahan data, distribusi responden dapat dilihat frekuensinya dari kategori jenis kelamin, pendidikan terakhir yang ditempuh, pendapatan per bulan, status pekerjaan, dan tingkat pengetahuan.

Berdasarkan data primer menurut kategori jenis kelamin responden peserta Posyandu Lansia di Puskesmas Bulak 
Banteng Surabaya tahun 2018, diperoleh data sebagai berikut:

Tabel 1. Karakteristik Responden berdasarkan Jenis Kelamin, Pendidikan, Pendapatan dan Pengetahuan

\begin{tabular}{lcc}
\hline Jenis Kelamin & Jumlah & Presentase \\
\hline Laki-Laki & 9 & $10,3 \%$ \\
Perempuan & 78 & $89,7 \%$ \\
Total & 87 & $100 \%$ \\
\hline Pendidikan & Jumlah & Presentase \\
\hline SD/Sederajat & 32 & $36,8 \%$ \\
SMP/Sederajat & 25 & $28,7 \%$ \\
SMA/Sederajat & 23 & $26,4 \%$ \\
S1 & 3 & $3,4 \%$ \\
S2 & 0 & $0 \%$ \\
S3 & 0 & $0 \%$ \\
Tidak Sekolah & 4 & $4,6 \%$ \\
Total & 87 & $100 \%$ \\
\hline Pendapatan & Jumlah & Presentase \\
\hline Rendah & 34 & $39,1 \%$ \\
Sedang & 32 & $36,8 \%$ \\
Tinggi & 21 & $24,1 \%$ \\
Total & 87 & $100 \%$ \\
\hline Pengetahuan & Jumlah & Presentase \\
\hline Rendah & 6 & $6,9 \%$ \\
Sedang & 43 & $49,4 \%$ \\
Tinggi & 38 & $43,7 \%$ \\
\hline Total & 87 & $100 \%$ \\
\hline & &
\end{tabular}

Berdasarkan tabel 1 menunjukkan bahwa mayoritas Lansia adalah berjenis kelamin perempuan yaitu sejumlah 78 Lansia (89,7\%), menempuh pendidikannya hingga tamat SD sejumlah 32 Lansia $(36,8 \%)$, berpendapatan rendah $(<\mathrm{Rp} 500.000)$ yaitu berjumlah 34 Lansia $(39,1 \%)$, serta memiliki pengetahuan rendah yaitu berjumlah 6 Lansia $(6,9 \%)$.

Jenis kelamin berpengaruh terhadap pemanfaatan Posyandu Lansia dimana responden dengan jenis kelamin perempuan lebih memanfaatkan Posyandu Lansia. Hal ini karena perempuan lebih peka dan sensitif terhadap masalah kesehatan yang dialaminya, sehingga perempuan lebih sering menggunakan fasilitas-fasilitas kesehatan untuk memelihara kesehatannya (Heniwati, 2008). Selain itu perempuan merupakan sosok ibu bagi anak-anaknya dan memiliki bawaan keibuan yang bertanggung jawab penuh terhadap kondisi keluarga dan dirinya terutama dalam aspek kesehatan.

Dalam variabel pendapatan mayoritas lansia mempunyai pendapatan dalam kategori rendah yaitu dibawah $\mathrm{Rp}$ 500.000. Lansia yang memiliki pendapatan kategori rendah mencapai $39,1 \%$. Namun hal ini tidak jauh berbeda dengan Lansia yang memiliki pendapatan sedang yaitu sebesar 36,8\% serta Lansia berpendapatan tinggi yaitu sebanyak $24,1 \%$. Hal ini menggambarkan bahwa mayoritas lansia memiliki pendapatan yang cukup untuk mengakses Posyandu Lansia dan aktif mengikutinya.

Mayoritas para Lansia menempuh pendidikannya dengan tamat $\mathrm{SD} /$ Sederajat. Sejalan dengan penelitian (Anita, 2014) yang telah dilakukan bahwa tingkat pendidikan Lansia sangat berpengaruh terhadap tingkat pengetahuan yang dimilikinya. Lansia dengan pendidikan rendah akan memiliki tingkat pengetahuan cukup dimana pengetahuan diperoleh dari pengalaman dan informasi yang telah mereka dapatkan. Sehingga mereka mampu untuk menerima perilaku yang didasari oleh pengetahuan mereka. Hal ini sejalan dengan pernyataan Notoadmodjo (2003) bahwa apabila seseorang mampu untuk menerima perilaku baru atau adopsi perilaku melalui proses yang didasari oleh pengetahuan dan sikap, maka perilaku tersebut akan bersifat jangka panjang (long lasting), sebaliknya apabila suatu perilaku tidak didasari oleh pengetahuan dan kesadaran, maka perilaku tersebut bersifat jangka pendek. Oleh karena itu, para lansia aktif dalam mengikuti kegiatan Posyandu Lansia karena mereka dapat menentukan kegiatan mana yang baik untuk dilakukan dan mana yang tidak baik untuk dilakukan untuk dirinya. Sehingga perilaku yang mereka kerjakan dapat bersifat jangka panjang (long lasting).

Berdasarkan tabel 2 dapat dilihat bahwa mayoritas responden memiliki Sikap terhadap Perilaku yang sangat baik terhadap keaktifan mengikuti Posyandu Lansia yaitu sebesar 59 Lansia (67,8\%), Norma Subyektif yang sangat baik 
Tabel 2. Distribusi Responden Berdasarkan Sikap Terhadap Perilaku, Norma Subyektif, Kontrol Perilaku yang Dirasakan dan Niat Aktif Mengikuti Posyandu Lansia

\begin{tabular}{llc}
\hline $\begin{array}{l}\text { Sikap Terhadap } \\
\text { Perilaku }\end{array}$ & Jumlah & Presentase \\
\hline Kurang Baik & 14 & $16,1 \%$ \\
Baik & 14 & $16,1 \%$ \\
Sangat Baik & 59 & $67,8 \%$ \\
\hline Norma Subyektif & Jumlah & Presentase \\
\hline Kurang Baik & 8 & $9,2 \%$ \\
Baik & 11 & $12,6 \%$ \\
Sangat Baik & 68 & $78,2 \%$ \\
Total & 87 & $100 \%$ \\
\hline Kontrol Perilaku & Jumlah & Presentase \\
yang Dirasakan & 11 & $12,6 \%$ \\
\hline Kurang Baik & 8 & $9,2 \%$ \\
Baik & 68 & $78,2 \%$ \\
Sangat Baik & 87 & $100 \%$ \\
Total & Jumlah & Presentase \\
\hline Niat & 30 & $34,5 \%$ \\
\hline Tidak Memiliki & 57 & $65,5 \%$ \\
Memiliki & 87 & $100 \%$ \\
\hline Total & & \\
\hline
\end{tabular}

terhadap keaktifan mengikuti Posyandu Lansia yaitu sebesar 68 Lansia $(78,2 \%)$, Kontrol Perilaku yang dirasakan yang sangat baik terhadap keaktifan mengikuti Posyandu Lansia yaitu sebesar 68 Lansia $(78,2 \%)$ dan niat untuk aktif mengikuti Posyandu Lansia yaitu sebesar 57 responden $(65,5 \%)$.

Sikap dapat dibentuk oleh pengetahuan yang baik terhadap suatu perilaku tertentu. Sikap terhadap perilaku keaktifan Lansia dapat berupa keyakinan bahwa mengikuti Posyandu Lansia dapat memberikan dampak baik bagi kesehatan dan kehidupan mereka serta penilaian apakah aktif mengikuti Posyandu Lansia merupakan hal yang baik dan tepat untuk mereka lakukan. Lansia dengan tingkat pendidikan tinggi memungkinkan untuk memiliki sikap yang baik untuk aktif mengikuti Posyandu Lansia.

Lansia merupakan seseorang yang sedang menempuh masa akhir kehidupannya, sehingga telah memiliki kedewasaan yang sangat matang terkait sikap untuk mengikuti lingkungannya. Dengan lingkungan yang mendukung untuk berperilaku aktif mengikuti Posyandu Lansia akan memunculkan norma subyektif yang mendukung bagi responden. Norma subyektif yang baik dapat digambarkan melalui motivasi yang kuat untuk patuh terhadap keluarga, teman, dan masyarakat disekitarnya. Selain itu norma subyektif juga menggambarkan bahwa dengan mematuhi pendapat orang di sekitar bahwa aktif mengikuti Posyandu Lansia adalah pilihan yang baik, merupakan hal yang tepat. Dapat disimpulkan bahwa responden memiliki keyakinan yang baik untuk mengikuti lingkungannya.

Kontrol perilaku bisa dibentuk berdasarkan tingkat kemudahan atau kesulitan untuk memunculkan perilaku. Kontrol perilaku yang dirasakan untuk mengikuti Posyandu Lansia ini yakni berupa kemudahan akses, baik jarak, tenaga maupun waktu. Selain itu, kontrol perilaku yang dirasakan juga berupa keyakinan bahwa responden mampu untuk menjangkau perilaku aktif mengikuti Posyandu Lansia. Mayoritas responden telah memiliki kemudahan untuk aktif mengikuti Posyandu Lansia, tetapi masih ditemukan juga beberapa responden yang mungkin kesulitan untuk aktif mengikuti Posyandu Lansia.

Dapat dikatakan bahwa mayoritas peserta Posyandu Lansia Puskesmas Bulak Banteng Surabaya memiliki keinginan yang kuat untuk memenuhi kebutuhan jasmani dan rohani agar tetap terjaga kesehatannya dengan aktif mengikuti Posyandu Lansia. Hal ini dapat dapat dipengaruhi oleh sikap, norma subyektif, dan kontrol perilaku (Azjen, 2005).

Tabel 3 menunjukkan mayoritas responden dengan sikap yang sangat baik memiliki niat untuk aktif mengikuti Posyandu Lansia. Beberapa responden dengan sikap yang sangat baik ada yang tidak memiliki niat untuk aktif mengikuti Posyandu Lansia. Hal ini menunjukkan bahwa responden dengan sikap terhadap perilaku yang baik tidak selalu mempunyai niat untuk aktif mengikuti Posyandu Lansia. Berdasarkan hasil uji 
Tabel 3. Tabulasi Silang antara Sikap Terhadap Perilakudengan Niat Aktif Mengikuti Posyandu Lansia di Puskesmas Bulak Banteng Surabaya Tahun 2018

\begin{tabular}{|c|c|c|c|c|c|c|}
\hline \multirow{3}{*}{$\begin{array}{l}\text { Sikap } \\
\text { Terhad } \\
\text { ap } \\
\text { Perilak } \\
\text { u }\end{array}$} & \multicolumn{4}{|c|}{ Niat } & \multirow{2}{*}{\multicolumn{2}{|c|}{ Total }} \\
\hline & & + & & - & & \\
\hline & $\mathbf{n}$ & $\%$ & $\mathbf{n}$ & $\%$ & $\mathbf{n}$ & $\%$ \\
\hline $\begin{array}{l}\text { Kurang } \\
\text { Baik }\end{array}$ & $\begin{array}{l}1 \\
0\end{array}$ & 71,4 & 4 & $\begin{array}{l}28, \\
5\end{array}$ & $\begin{array}{l}1 \\
4\end{array}$ & 100 \\
\hline Baik & 4 & 28,5 & 10 & $\begin{array}{l}71, \\
4\end{array}$ & $\begin{array}{l}1 \\
4\end{array}$ & 100 \\
\hline $\begin{array}{l}\text { Sangat } \\
\text { Baik }\end{array}$ & $\begin{array}{l}1 \\
6\end{array}$ & 27,1 & 43 & $\begin{array}{l}72, \\
8\end{array}$ & $\begin{array}{l}5 \\
9\end{array}$ & 100 \\
\hline
\end{tabular}

regresi logistik sederhana antara sikap terhadap perilaku dan niat aktif mengikuti Posyandu Lansia didapatkan nilai signifikansi sebesar 0,008. Angka ini lebih kecil dari nilai $\alpha=0,05$. Dapat dikatakan bahwa ada pengaruh yang signifikan antara sikap terhadap perilaku dan niat aktif mengikuti Posyandu Lansia.

Tabel 4. Tabulasi Silang antara Norma Subyektif dengan Niat Aktif Mengikuti Posyandu Lansia di Puskesmas Bulak Banteng Surabaya Tahun 2018

\begin{tabular}{|c|c|c|c|c|c|c|}
\hline \multirow{3}{*}{$\begin{array}{l}\text { Norma } \\
\text { Subyektif }\end{array}$} & \multicolumn{4}{|c|}{ Niat } & \multirow{2}{*}{\multicolumn{2}{|c|}{ Total }} \\
\hline & & + & & - & & \\
\hline & n & $\%$ & $\mathrm{n}$ & $\%$ & $\mathrm{n}$ & $\%$ \\
\hline $\begin{array}{l}\text { Kurang } \\
\text { Baik }\end{array}$ & 2 & 25 & 6 & 75 & 8 & $\begin{array}{l}10 \\
0\end{array}$ \\
\hline Baik & 1 & $\begin{array}{l}9,0 \\
9\end{array}$ & 10 & $\begin{array}{l}90, \\
9\end{array}$ & $\begin{array}{l}1 \\
1\end{array}$ & $\begin{array}{l}10 \\
0\end{array}$ \\
\hline $\begin{array}{l}\text { Sangat } \\
\text { Baik }\end{array}$ & 7 & $\begin{array}{l}39, \\
7\end{array}$ & 41 & $\begin{array}{l}60, \\
3\end{array}$ & $\begin{array}{l}6 \\
8 \\
\end{array}$ & $\begin{array}{l}10 \\
0\end{array}$ \\
\hline
\end{tabular}

Tabel 4 menunjukkan mayoritas responden dengan norma subyektif yang sangat baik memiliki niat untuk aktif mengikuti Posyandu Lansia. Namun tetap ada beberapa responden dengan norma subyektif yang sangat baik tetapi masih belum memiliki niat untuk aktif mengikuti Posyandu Lansia. Hal ini menunjukkan bahwa responden dengan norma subyektif yang baik tidak selalu mempunyai niat untuk aktif mengikuti Posyandu Lansia. Berdasarkan hasil uji regresi logistik sederhana antara norma subyektif dan niat aktif mengikuti Posyandu Lansia didapatkan nilai signifikansi sebesar 0,105 . Angka ini lebih kecil dari nilai $\alpha=0,05$. Dapat dikatakan bahwa tidak ada pengaruh yang signifikan antara norma subyektif dan niat aktif mengikuti Posyandu Lansia.

Tabel 5. Tabulasi Silang antara Kontrol Perilaku yang Dirasakandengan Niat Aktif Mengikuti Posyandu Lansia di Puskesmas Bulak Banteng Surabaya Tahun 2018

\begin{tabular}{|c|c|c|c|c|c|c|}
\hline \multirow{3}{*}{$\begin{array}{l}\text { Kontro } \\
\text { l } \\
\text { Perilak } \\
\text { u yang } \\
\text { Dirasa } \\
\text { kan }\end{array}$} & \multicolumn{4}{|c|}{ Niat } & \multirow{2}{*}{\multicolumn{2}{|c|}{ Total }} \\
\hline & & + & & - & & \\
\hline & $\mathbf{n}$ & $\%$ & $\mathbf{n}$ & $\%$ & $\mathbf{n}$ & $\%$ \\
\hline $\begin{array}{l}\text { Kurang } \\
\text { Baik }\end{array}$ & 0 & 0 & 11 & $\begin{array}{l}10 \\
0\end{array}$ & $\begin{array}{l}1 \\
1\end{array}$ & $\begin{array}{l}1 \\
0 \\
0\end{array}$ \\
\hline Baik & 2 & 25 & 6 & 75 & 8 & $\begin{array}{l}1 \\
0 \\
0\end{array}$ \\
\hline $\begin{array}{l}\text { Sangat } \\
\text { Baik }\end{array}$ & $\begin{array}{l}2 \\
8\end{array}$ & $\begin{array}{l}41 \\
, 1\end{array}$ & 40 & $\begin{array}{l}58 \\
, 8\end{array}$ & $\begin{array}{l}6 \\
8\end{array}$ & $\begin{array}{l}1 \\
0 \\
0\end{array}$ \\
\hline
\end{tabular}

Tabel 5 menunjukkan mayoritas responden dengan kontrol perilaku yang baik juga memiliki niat untuk aktif mengikuti Posyandu Lansia. Tetapi dapat dilihat juga bahwa ada beberapa responden dengan kontrol perilaku yang baik namun tidak memiliki niat untuk aktif mengikuti Posyandu Lansia. Hal ini menunjukkan bahwa responden dengan kontrol perilaku yang dirasakan baik tidak selalu mempunyai niat untuk aktif mengikuti Posyandu Lansia. Berdasarkan hasil uji regresi logistik sederhana antara kontrol perilaku dan niat aktif mengikuti Posyandu Lansia didapatkan nilai signifikansi sebesar 0,002. Angka ini lebih kecil dari nilai $\alpha=0,05$. Dapat dikatakan bahwa ada pengaruh yang signifikan antara kontrol perilaku yang dirasakan dengan niat aktif mengikuti Posyandu Lansia. 
Tabel 6. Hasil Uji Regresi Pengaruh Sikap terhadap Perilaku, Norma Subyektif, dan Kontrol Perilaku yang Dirasakan terhadap Niat aktif mengikuti Posyandu Lansia di Puskesmas Bulak Banteng Surabaya Tahun 2018

\begin{tabular}{|c|c|c|c|}
\hline $\begin{array}{l}\text { Variabel } \\
\text { Bebas }\end{array}$ & $\begin{array}{l}\text { Variabel } \\
\text { Terikat }\end{array}$ & Sig & Pengaruh \\
\hline $\begin{array}{l}\text { Sikap } \\
\text { terhadap } \\
\text { Perilaku }\end{array}$ & \multirow{3}{*}{ Niat } & 0,008 & + \\
\hline $\begin{array}{l}\text { Norma } \\
\text { Subyektif } \\
\text { Kontrol }\end{array}$ & & 0,105 & - \\
\hline $\begin{array}{l}\text { Perilaku } \\
\text { yang } \\
\text { Dirasakan }\end{array}$ & & 0,002 & + \\
\hline \multicolumn{2}{|c|}{ Variabel Bebas } & \multicolumn{2}{|c|}{$\operatorname{Exp}(B)$} \\
\hline \multicolumn{2}{|c|}{$\begin{array}{l}\text { Sikap terhadap } \\
\text { Perilaku }\end{array}$} & \multicolumn{2}{|l|}{11,25} \\
\hline \multicolumn{2}{|c|}{$\begin{array}{l}\text { Kontrol Perilaku yang } \\
\text { Dirasakan }\end{array}$} & \multicolumn{2}{|l|}{0,236} \\
\hline
\end{tabular}

Berdasarkan hasil uji regresi yang terlihat pada tabel 6 , dari ketiga variabel bebas, yakni: sikap terhadap perilaku, norma subyektif, dan kontrol perilaku yang dirasakan, hanya variabel sikap terhadap perilaku dan variabel kontrol perilaku yang dirasakan yang menunjukkan adanya pengaruh signifikan terhadap niat untuk aktif mengikuti Posyandu Lansia. Hal ini dilihat dari besarnya nilai signifikansi yang lebih kecil dari $\alpha(0,05)$. Dengan demikian dapat dikatakan bahwa hanya variabel sikap terhadap perilaku dan variabel kontrol perilaku yang dirasakan, yang dapat digunakan untuk pendugaan niat aktif mengikuti Posyandu Lansia. Seperti yang diketahui sebelumnya, variabel yang mempengaruhi niat aktif mengikuti Posyandu Lansia adalah sikap terhadap perilaku dan variabel kontrol perilaku yang dirasakan. Kedua variabel ini yang kemudian dijadikan pendugaan dalam membandingkan besarnya kemungkinan Lansia yang memiliki niat untuk aktif mengikuti Posyandu Lansia dibanding dengan yang tidak. Besarnya pembandingan tersebut dilihat berdasarkan nilai Exp (B) dari masing- masing variabel, dapat dilihat bahwa responden dengan variabel sikap terhadap perilaku yang baik memiliki niat untuk aktif mengikuti Posyandu Lansia 11,25 kali lebih besar dibandingkan dengan responden dengan variabel sikap terhadap perilaku yang kurang baik. Hal ini berarti responden dengan variabel sikap terhadap perilaku yang baik memiliki niat aktif mengikuti Posyandu Lansia yang lebih baik daripada responden dengan variabel sikap terhadap perilaku yang kurang baik.

Sedangkan untuk varibel kontrol perilaku yang dirasakan, dapat dilihat bahwa semakin baik kontrol perilaku yang dirasakan, maka niat untuk aktif mengikuti Posyandu Lansia akan meningkat 0,236 kalinya. Dapat disimpulkan juga semakin baik kontrol perilaku yang dirasakan, dapat menimbulkan niat untuk aktif mengikuti Posyandu Lansia.

\section{Sikap Lansia dalam Aktif Mengikuti Posyandu Lansia}

Sikap merupakan respon tertutup yang dihasilkan seseorang terhadap stimulus yang diterimanya, dengan melibatkan faktor pendapat dan emosi yang bersangkutan untuk setuju atau tidak setuju terhadap suatu perilaku (Notoadmodjo, 2005). Beberapa faktor yang mempengaruhi pembentukan sikap yaitu antara lain pengalaman pribadi, orang lain yang dianggap penting, dan pengaruh kebudayaan. Apabila individu benar-benar lepas dari segala tekanan atau hambatan yang bisa mengganggu ekspresi sikapnya, maka dapat diharapkan bentuk perilaku yang tampak sebagai bentuk ekspresi yang sebenarnya, dalam hal ini adalah berkunjung ke Posyandu Lansia. Sikap responden yang baik yaitu aktif mengikuti Posyandu Lansia dapat disebabkan karena pengetahuan responden yang baik. Adapun responden dengan pengetahuan rendah memiliki proporsi paling rendah yaitu sejumlah $6,9 \%$. Sikap responden juga dipengaruhi oleh pengalaman pribadi responden saat berkunjung ke Posyandu (Lestari, 2011).

Berdasarkan Theory of Planned Behavior yang dikemukakan oleh Ajzen (2005), sikap terhadap perilaku ditentukan oleh keyakinan terhadap konsekuensi 
yang timbul dari suatu perilaku yang ditampilkan. Ajzen menyatakan bahwa belief dapat diungkapkan dengan cara menghubungkan suatu perilaku dengan berbagai manfaat atau kerugian yang mungkin diperoleh apabila kita melakukan atau tidak melakukan perilaku itu.

Theory of Planned Behavior merupakan teori yang menyatakan bahwa ada 2 variabel yang dapat mempengaruhi sikap, yaitu kepercayaan dan penilaian objek (Ajzen, 2005). Pandangan sikap terhadap perilaku dalam penelitian ini digambarkan dengan memberikan pilihan sangat setuju, setuju, tidak setuju atau sangat tidak setuju dengan jawaban berupa skala 1-6 dalam menanggapi pernyataan seputar mengikuti Posyandu Lansia dalam bepntuk kuesioner. Pembahasan sikap terhadap perilaku dijabarkan melalui pandangan terhadap kepercayaan dan penilaian objek dalam mengikuti Posyandu Lansia.

Kepercayaan dalam berperilaku Lansia digambarkan dengan pernyataan mengenai manfaat mengikuti Posyandu Lansia. Mayoritas responden dalam penelitian ini memiliki pandangan positif yaitu setuju terhadap keyakinan berperilaku untuk mengikuti Posyandu Lansia. Sedangkan penilaian objek didasari pada keyakinan terhadap suatu kegiatan yang telah dirasakan melalui panca indera dengan mengikuti Posyandu Lansia.

Berdasarkan hasil penelitian, terdapat 59 Lansia yang memiliki tingkat sikap terhadap perilaku yang sangat baik untuk mengikuti Posyandu Lansia. Mayoritas responden setuju pada pernyataan yang mengatakan bahwa aktif mengikuti Posyandu Lansia merupakan pilihan yang tepat. Lansia beranggapan bahwa dengan mengikuti Posyandu Lansia dapat memberikan manfaat untuk kesehatannya. Sejalan dengan penelitian Suseno (2012), apabila Lansia telah mengetahui manfaat dari Posyandu Lansia, maka saat Lansia sedang mengalami keluhan fisik pun, mereka akan tetap aktif mengikuti Posyandu Lansia. Selain alasan untuk memeriksakan kondisi kesehatan, Lansia datang berkunjung ke Posyandu untuk bertemu dengan teman-teman seusianya maupun dengan petugas kesehatan sebagai ajang menjalin tali silaturahim.

Dalam penelitian ini sikap diukur melalui manfaat aktif mengikuti Posyandu Lansia bagi responden. Keyakinan ini yang nantinya akan dijadikan dugaan terhadap niat untuk aktif mengikuti Posyandu Lansia. Hasil penelitian menunjukkan bahwa sebanyak 67,8\% responden memiliki sikap yang sangat baik terkait perilaku aktif mengikuti Posyandu Lansia. Sikap yang sangat baik ini menunjukkan bahwa Peserta Posyandu Lansia di wilayah kerja Puskesmas Bulak Banteng memiliki sikap yang positif dalam mendukung terbentuknya niat aktif mengikuti Posyandu Lansia.

\section{Norma Subyektif Lansia dalam Aktif Mengikuti Posyandu Lansia}

Norma subyektif merupakan persepsi individu terhadap tekanan sosial yang ada untuk menampilkan atau tidak menampilkan suatu perilaku dan kesediaan untuk mematuhi tuntutan dari tokoh yang penting menurut dirinya (Ajzen, 2005). Dalam penelitian ini tokoh yang dianggap penting adalah keluarga, teman dan pandangan masyarakat. Ketiga tokoh tersebut memberikan kontribusi dalam mempengaruhi niat lansia untuk aktif mengikuti Posyandu Lansia. Lingkungan sosial memiliki pengaruh yang cukup besar terhadap terjadinya suatu perilaku, karena kebiasaan yang menghasilkan norma sosial dan telah dijalani secara turun temurun atau kebiasaan (Kurniawati, 2015).

Norma subyektif dalam penelitian ini diartikan sebagai pandangan Lansia terhadap kepercayaan tentang tanggapan yang dimiliki orang lain atau keluarga yang sering berada di sekitar Lansia dalam mempengaruhi dirinya untuk menentukan suatu niat aktif mengikuti Posyandu Lansia. Pandangan norma subyektif dalam penelitian ini digambarkan dengan memberikan pilihan sangat setuju, setuju, tidak setuju atau sangat tidak setuju dengan jawaban berupa skala 1-6 dalam menanggapi pernyataan seputar keikutsertaan Posyandu Lansia dalam bentuk kuesioner. Pembahasan norma subyektif terdiri dari kepercayaan tentang tanggapan dan 
motivasi untuk patuh terhadap pendapat orang sekitar untuk menuruti perilaku.

Motivasi untuk menuruti perilaku yang dimiliki Lansia untuk mengikuti Posyandu Lansia didapat dari stimulus dari luar diri Lansia atau dukungan lingkungan sekitar yang dapat mempengaruhi niatnya. Teman atau orang terdekat merupakan sumber dorongan terkuat Lansia dalam mengikuti Posyandu Lansia. Widjajono (2009) menyatakan kurangnya motivasi pada responden menjadikan responden tidak aktif mengikuti kegiatan Posyandu Lansia. Motivasi lansia dapat dipengaruhi oleh motivasi intrinsik dan ekstrinsik. Motivasi intrinsik pada lansia merupakan sebuah keinginan yang muncul dari diri sendiri tanpa adanya dukungan orang lain. Sedangkan motivasi ektrinsik ialah motivasi individu yang dipengaruhi oleh orang sekitar, dalam hal ini ialah keluarga, teman atau masyarakat sekitar.

Berdasarkan hasil penelitian mayoritas peserta Posyandu Lansia Puskesmas Bulak Banteng Surabaya memiliki norma subyektif yang sangat baik yakni sebesar 68 Lansia $(78,2 \%)$. Mayoritas responden setuju pada pernyataan yang mengatakan bahwa menurut keluarga, aktif mengikuti Posyandu Lansia adalah suatu hal yang harus dilakukan. Banyaknya responden yang memiliki norma subyektif yang baik tentunya tidak hanya dipengaruhi oleh tuntutan keluarga, teman, masyarakat atau tokoh penting, namun berkaitan juga dengan keinginan responden untuk memenuhi tuntutan tersebut.

Fakta di lapangan menunjukkan bahwa para lansia merasa senang ketika kegiatan Posyandu Lansia diselenggarakan. Hal ini disebabkan karena Posyandu Lansia telah menjadi rutinitas dan kebiasaan yang dilakukan oleh masyarakat untuk refreshing, berkumpul dengan teman sebaya, mendapat pengobatan gratis dan melepas kejenuhan akibat aktivitas yang monoton di rumah. Hal tersebut dapat menjadi faktor penguat sehingga lansia dapat tetap aktif mengikuti Posyandu Lansia.

\section{Kontrol Perilaku Yang Dirasakan Lansia dalam Aktif Mengikuti Posyandu Lansia}

Kontrol perilaku yang dirasakan, menurut Theory of Planned Behavior (Ajzen, 2005) diasumsikan sebagai suatu keyakinan mengenai ada atau tidaknya berbagai faktor yang memfasilitasi atau menghalangi dalam menampilkan suatu perilaku tertentu. Keyakinan ini dapat didasari oleh pengalaman masa lalu, tetapi juga bisa dipengaruhi oleh informasi yang didapat dari orang lain. Selain itu juga dipengaruhi oleh faktor lain yang meningkatkan atau menurunkan persepsi mengenai kesulitan untuk menampilkan suatu perilaku tertentu.

Kontrol perilaku yang dirasakan dapat dipengaruhi oleh pendidikan dan tingkat pengetahuan. Lansia yang bersekolah akan lebih mudah menerima informasi daripada yang tidak bersekolah. Sehingga mereka dapat mengontrol diri mereka dengan mengikuti kegiatan yang baik menurut pendapatnya. Sejalan dengan penelitian Endang (2013), bahwa informasi yang diterima oleh para Lansia yang tidak sekolah akan lebih sedikit, khususnya tentang Posyandu Lansia karena dapat berdampak pada kesulitan pemahaman lansia mengenai apa yang diinformasikan kepada lansia tersebut.

Pandangan kontrol perilaku yang dirasakan dalam penelitian ini digambarkan dengan memberikan pilihan sangat setuju, setuju, tidak setuju atau sangat tidak setuju dengan jawaban berupa skala 1-6 dalam menanggapi pernyataan seputar kemudahan dan kepercayaan tentang kemampuan untuk mengikuti Posyandu Lansia dalam bentuk kuesioner. Pembahasan kontrol perilaku yang dirasakan terdiri dari kontrol perilaku tentang kemudahan dan kemampuan dalam pengambilan keputusan untuk aktif mengikuti Posyandu Lansia.

Dalam penelitian ini faktor yang digunakan sebagai tolak ukur kemudahan atau kesulitan menampilkan perilaku adalah kemampuan lansia untuk meluangkan waktu, kemudahan akses, dan akibat kedepannya dalam memunculkan perilaku. Dari hasil penelitian, mayoritas 
responden dapat dikatakan memiliki kontrol perilaku yang sangat baik yakni mencapai 68 lansia (78,2\%). Mayoritas responden setuju pada pernyataan yang mengatakan bahwa responden percaya bahwa responden mampu mengakses kegiatan Posyandu Lansia. Hal ini menunjukkan bahwa mayoritas responden merasa mudah untuk aktif mengikuti Posyandu Lansia.

Berdasarkan fakta di lapangan, responden merasa mudah dan mampu untuk sekedar berjalan menuju tempat diselenggraakannya Posyandu Lansia dikarenakan letaknya yang tidak berada jauh dari tempat mereka tinggal. Hal ini sejalan dengan pernyataan Chung Chang (2005, dalam Bachtiar, 2009) yang berpendapat bahwa jika orang merasa mudah untuk mengontrol perilakunya (memilki pengetahuan, kemampuan, dan sarana), maka ia akan semakin berusaha atau berniat untuk melakukan perilaku tersebut dan demikian pula sebaliknya.

\section{Niat Lansia dalam Aktif Mengikuti Posyandu Lansia}

Niat atau intensi menurut Ajzen (1985), merupakan komponen dalam diri individu yang mengacu pada keinginan untuk melakukan tingkah laku tertentu. Intensi adalah kesungguhan niat seseorang untuk melakukan perbuatan atau memunculkan suatu perilaku tertentu. Intensi menghubungkan antara pertimbangan yang mendalam, yang diyakini dan diinginkan oleh seseorang dengan tindakan tertentu.

Niat lansia dalam penelitian ini merupakan suatu keinginan yang dimiliki lansia untuk mengikuti Posyandu Lansia yang didasarkan pada sikap terhadap perilaku, norma subyektif serta kontrol perilaku yang dirasakan. Niat lansia untuk mengikuti Posyandu Lansia merupakan langkah sebelum terjadinya perilaku untuk aktif mengikuti Posyandu Lansia.

Dalam penelitian niat diukur berdasarkan keinginannya untuk melakukan perilaku disaat ini dan yang akan datang. Mayoritas responden telah memiliki niat untuk aktif mengikuti Posyandu Lansia yakni sebesar 57 Lansia $(65,5 \%)$. Hal ini menunjukkan mayoritas peserta Posyandu Lansia memiliki niat yang positif untuk memunculkan perilaku aktif mengikuti Posyandu Lansia.

Fakta di lapangan menunjukkan bahwa, mayoritas lansia yang berniat aktif mengikuti Posyandu Lansia berpendapat bahwa lansia menginginkan dirinya sehat. Niat yang baik akan mendorong timbulnya motivasi untuk berbuat baik. Tindakan yang baik akan memberikan hasil yang baik pula. Apabila hal ini dilakukan secara terus menerus, maka akan terinternalisasi dan persisten dalam diri seseorang. Sehingga akan tercipta pribadi dengan perilaku yang baik, begitu pula sebaliknya. Selain untuk menginginkan dirinya sehat, salah satu manfaat mengikuti Posyandu Lansia juga untuk meningkatkan taraf kehidupan, sehingga dapat menjadi lansia yang produktif. Disamping itu, manfaat juga akan dirasakan oleh keluarga lansia yang aktif mengikuti Posyandu Lansia karena rutin memeriksa kesehatannya, yaitu dengan tidak mengeluarkan biaya yang lebih besar untuk membeli obat karena lansia sakit.

\section{Faktor yang Mempengaruhi Niat Aktif Mengikuti Posyandu Lansia di Puskesmas Bulak Banteng Surabaya}

Hasil analisis regresi logistik didapatkan hanya variabel sikap terhadap perilaku dan kontrol perilaku yang dirasakan yang berpengaruh secara signifikan terhadap niat aktif mengikuti Posyandu Lansia. Uji regresi logistik dilakukan untuk melihat pengaruh sikap terhadap perilaku, norma subyektif dan kontrol perilaku yang dirasakan terhadap niat aktif mengikuti Posyandu Lansia.

Berdasarkan sikap terhadap perilaku responden menunjukkan bahwa semakin baik sikap lansia, maka niat untuk aktif mengikuti Posyandu Lansia akan semakin kuat. Hal ini dilihat berdasarkan nilai Exp (B) sikap terhadap niat sebersar 11,25. Dapat dikatakan bahwa semakin baik sikap maka niat untuk aktif mengikuti Posyandu Lansia akan meningkat 11,25 kalinya. Sesuai dengan Theory of Planned Behavior yang ditulis oleh Ajzen (2005) yang menyebutkan bahwa sikap terhadap perilaku merupakan salah satur faktor pembentuk niat untuk berperilaku. 
Berdasarkan kontrol perilaku yang dirasakan menunjukkan bahwa responden dengan kontrol perilaku baik memiliki niat yang lebih besar daripada responden dengan kontrol perilaku kurang baik untuk aktif mengikuti Posyandu Lansia. Hal ini dapat dilihat berdasarkan nilai Exp (B) kontrol perilaku yang dirasakan terhadap niat sebesar 0,236 . Nilai tersebut menunjukkan bahwa responden dengan kontrol perilaku baik memiliki niat 0,236 kali lebih kuat daripada responden dengan kontrol perilaku kurang baik untuk aktif mengikuti Posyandu Lansia.

Dalam Theory of Planned Behavior disebutkan bahwa dari ketiga variabel yang paling berpengaruh adalah variabel yang paling dianggap penting (Ajzen, 2005). Hal ini menunjukkan bahwa sikap memberikan pengaruh paling besar terhadap niat aktif mengikuti Posyandu Lansia. Sesuai dengan penelitian Rusdin (2011) terkait pemilihan penolong persalinan, bahwa variabel sikap terhadap perilaku merupakan variabel yang paling berpengaruh terhadap niat.

Dalam penelitian ini, norma subyektif tidak menunjukkan pengaruh yang signifikan terhadap niat untuk aktif mengikuti Posyandu Lansia. Hal ini tidak sesuai dengan Theory of Planned Behavior (Azjen, 2005) bahwa norma subyektif merupakan variabel yang mempengaruhi niat. Norma subyektif seseorang dipengaruhi oleh sejauh mana orang yang dianggap penting (Referent) akan mendukung atau melarang perilaku tersebut. Dapat disimpulkan bahwa pengaruh referent belum tentu bisa memberikan pengaruh terhadap niat responden untuk aktif mengikuti Posyandu Lansia. Norma subyektif merupakan faktor yang didapat dari luar yaitu berupa motivasi ekstrinsik, sehingga bersifat kondisional. Hal ini diperkuat oleh fakta di lapangan yang menunjukkan bahwa banyak lansia yang hidup sebatang kara karena kehilangan pasangan hidupnya dan atau jauh dari keluarga, terutama anaknya yang merantau ke luar kota. Tentunya hal ini dianggap penting bagi lansia yang sedang menempuh masa akhir kehidupannya. Sehingga intensitas untuk mendapatkan masukan dari kelompok lain atau keluarganya menjadi rendah. Menurut Alberta (2014), adapun dampak psikologis yang terjadi pada Lansia juga dipengaruhi oleh tipe kepribadian Lansia. Pada tipe kepribadian yang tergantung, bermusuhan atau kritik diri lebih sulit untuk menerima masukan dari orang lain karena orang yang paling penting bagi dirinya adalah pasangan hidupnya yang telah tiada. Norma subyektif dibentuk oleh dua faktor, yaitu faktor keyakinan saran dan motivasi menuruti saran.

\section{SIMPULAN}

Mayoritas responden memiliki tingkat pengetahuan sedang tentang keaktifan mengikuti Posyandu Lansia. Sebagian besar responden memiliki sikap terhadap perilaku, norma subyektif dan kontrol perilaku yang dirasakan yang sangat baik dalam aktif mengikuti Posyandu Lansia. Sikap terhadap perilaku dan Kontrol Perilaku yang dirasakan berpengaruh terhadap niat responden untuk aktif mengikuti Posyandu Lansia. Sedangkan Norma subyektif tidak berpengaruh terhadap niat responden untuk aktif mengikuti Posyandu Lansia.

\section{DAFTAR PUSTAKA}

Ajzen, I. 1985. From intentions to actions: A Theory of Planned Behavior. In J. Kuhl \& J. Beckman (Eds.), Actioncontrol: From cognition to behavior (pp.11-39). Germany: Springer.

Ajzen, I. 2005. Attitudes, Personality and Behavior, 2nd Edition. Maidenhead : Open University Press

Alberta, Lembunai Tat, dkk. 2014. Peningkatan Perilaku Diet Rendah Garam BerbasisTheory Of Planned Behavior (TPB) Pada Lansia Penderita Hipertensi. Jurnal Ners Vol. 9 No. 2.

Anita, Nur. 2014. Gambaran Tingkat Pengetahuan Lansia Tentang Diit Hipertensi Di Posyandu Lansia Sehat Mandiri Purwogondo Kartasura Sukoharjo. Jurnal Promosi Kesehatan, $2014: 2(1)$. 
Bachtiar, Handitya. 2009. Analisis Pengaruh Sikap, Norma Subyektif, Kontrol Perilaku, Persepsi Manfaat, Dan Persepsi Kemudahan Terhadap Niat Konsumen Menggunakan Internet Untuk Melakukan Belanja Online Kembali Di Surabaya. Jurnal bisnis dan akuntansi, 2009:4(2).

Data Peserta Posyandu Lansia Dinas Kesehatan Kota Surabaya, 2017.

Endang \& Mamik, R. 3013. Hubungan antara pengetahuan dengan keaktifan Lansia datang ke Posyandu Lansia di dusun kudu desa kudu banjar kecamatan kudu kabupaten jombang tahun 2013. Jurnal Metabolisme 2013: 2(3).

Heniwati. 2008. Faktor-Faktor Yang Mempengaruhi Pemanfaatan Pelayanan Posyandu Lansia di Wilayah Kerja Puskesmas Kabupaten Aceh Timur [Tesis]. Universitas Sumatera Utara.

Kementerian Kesehatan Republik Indonesia. 2014. Situasi dan analisis lanjut usia. Jakarta Selatan: Pusat Data dan Informasi Kementerian Kesehatan Republik Indonesia.

Kementerian Kesehatan Republik Indonesia. Infodatin Pusat Data dan Informasi. 2016. Situasi Lanjut Usia (Lansia) di Indonesia. In: RI KK, editor. Indonesia : Kementrian Kesehatan RI.

Kurniawati, I. 2015. Pengaruh Pengetahuan, Motivasi Dan Dukungan Suami Terhadap Perilaku Pemeriksaan Iva Pada Kelompok Wanita Usia Subur Di Puskesmas Kedungrejo [Tesis]. Surakarta : Universitas Sebelas Maret.

Lestari, P, dkk. 2011. Beberapa Faktor Yang Berperan Terhadap Keaktifan Kunjungan Lansia Ke Posyandu (Studi Kasus Di Desa Tamantirto Kecamatan Kasihan Kabupaten Bantul Provinsi DIY). MMI 2011:42(2). Diakses di http://id.portalgaruda.org pada tanggal 4 April 2018
Notoadmodjo, S. 2003. Prinsip-Prinsip Dasar Ilmu Kesehatan Masyarakat. Jakarta : Rineka Cipta.

Notoadmodjo, S. 2005. Promosi Kesehatan (Teori dan Aplikasi). Jakarta : Rineka Cipta.

Peraturan Derah Kota Surabaya Nomor 3 Tahun 2014 Tentang Kesejahteraan Lanjut Usia.

Rusdin. 2011. Pengaruh Sikap Terhadap Perilaku, Norma Subyektif dan Kontrol Perilaku Yang Dirasakan Terhadap Tindakan Memilih Penolong Persalinan Di Puskesmas Rasana'e Timur Kota Bima [Skripsi]. Surabaya : Universitas Airlangga.

Suardiman, S. 2011. Psikologi Usia Lanjut. Yogyakarta: Gadjah Mada University Press.

Suseno, Dian Mahara. 2012. FaktorFaktor yang Mempengaruhi Keaktifan Lansia Dalam Mengikuti Kegiatan Posyandu Lansia di Desa Kauman Kecamatan Polanharjo Kabupaten Klaten [jurnal]. Surakarta: Universitas Muhammadiyah Surakarta.

Undang-Undang Republik Indonesia Nomor 13 Tahun 1998 Tentang Kesejahteraan Lanjut Usia.

Undang-Undang Republik Indonesia Nomor 36 Tahun 2009 Tentang Kesehatan. Jakarta : Sekretariat Negara.

United Nations. 2013. World Population Ageing 2013. Diakses pada 7 Oktober 2017

di http://www.un.org/en/development/desa/p opulation/publications/pdf/ageing/WorldP opulationAgeing2013.pdf

Widjajono, U. 2009. Berbagai Faktor Yang Berpengaruh Terhadap Partisipasi Lansia Dalam Kegiatan Posyandu Plus Di Dusun Soragan, Desa Ngestiharjo Kecamatan Kasihan Kabupaten Bantul. Poltekkes Depkes Yogyakarta. 